\title{
Does the seed disperser matter? The influence of dispersal type on survival of Araucaria angustifolia seeds
}

Larissa Inês Squinzani ( $\square$ larissaisquinzani@gmail.com )

Universidade Estadual do Oeste do Paraná: Universidade Estadual do Oeste do Parana https://orcid.org/0000-0002-0655-021X

Pitágoras Augusto Piana

UNIOESTE: Universidade Estadual do Oeste do Parana

Carlos Rodrigo Brocardo

Universidade Federal do Oeste do Para - Campus Tapajos: Universidade Federal do Oeste do Para

Research Article

Keywords: seed dispersal patterns, Paraná pine, scatter-hoarding animals, seed predation

Posted Date: December 6th, 2021

DOI: https://doi.org/10.21203/rs.3.rs-1114990/v1

License: (c) (i) This work is licensed under a Creative Commons Attribution 4.0 International License. Read Full License 
1 Does the seed disperser matter? The influence of dispersal type on survival of Araucaria angustifolia seeds

2 Larissa Inês Squinzani' ${ }^{1}$, Pitágoras Augusto Piana², Carlos Rodrigo Brocardo ${ }^{3,4}$

31 Programa de Pós-Graduação em Conservação e Manejo de Recursos Naturais da Universidade Estadual do Oeste

4 do Paraná- Unioeste, Cascavel, Paraná, Brasil.

52 Programa de Pós-Graduação em Conservação e Manejo de Recursos Naturais da Universidade Estadual do Oeste

6 do Paraná- Unioeste, Cascavel, Paraná, Brasil.

7 3Universidade Federal do Oeste do Pará, Santarém, Pará, Brasil

$8 \quad{ }^{4}$ Instituto Neotropical: Pesquisa e Conservação, Curitiba, Paraná, Brasil

9 Email: larissaisquinzani@gmail.com, pitapiana@yahoo.com.br, brocardocarolus@gmail.com.

10 Declarations

11 Funding: CAPES (Coordination for the Improvement of Higher Education Personnel), case number:

$1288882.441522 / 2019-01$, for the master's scholarship granted to LIS that enabled the work to be carried out. CRB

13 received a CAPES postdoctoral fellowship (Finance code \#001).

14 Conflicts of interest/Competing interests: Not applicable

15 Availability of data and material: All data used are within the article.

16 Code availability: Null.

17 Authors' contributions: Larissa Inês Squinzani: conceived and designed the analysis; collected the data;

18 contributed data or analysis tools; performed the analysis; wrote the paper. Pitágoras Augusto Piana: conceived and

19 designed the analysis; contributed data or analysis tools; performed the analysis. Carlos Rodrigo Brocardo:

20 conceived and designed the analysis; contributed data or analysis tools; performed the analysis.

21 Ethics approval: Not applicable

22 Consent to participate: Not applicable

23 Consent for publication: Not applicable

\section{ACKNOWLEDGMENT}

The authors would like to thank the collaborators of the City Zoo of Cascavel for their cooperation

27 conducting the experiments. The City Department of Environment of Cascavel for the authorization to search in the 28 requested location. The CAPES (Coordination for the Improvement of Higher Education Personnel), case number:

$2988882.441522 / 2019-01$, for the master's scholarship granted to LIS that enabled the work to be carried out. CRB is a 30 CAPES postdoctoral fellow (Finance code \#001). 


\section{1}

32

33

Zoochoric dispersion is fundamental for the colonization of habitats by plants with large and heavy seeds such as the Paraná pine (Araucaria angustifolia). This is an endangered conifer from South America whose recruitment is heavily impacted by animals, but the way that different zoochoric dispersal modes and deposition sites can affect its successful establishment is not known yet. Thus, in this study, we aimed to evaluate the effect of dispersal mode (accordingly to the seed disperser), distance from adult conspecifics, and disposition site on long-term recruitment success. The experimental design included two environments (forest and open field) and each of them received 30 micro-habitat sampling stations (simulating deposition sites: 10 under conspecific; 10 far from conspecifics, next to a landmark; and 10 far from conspecifics, without a landmark), and each microhabitat had three levels of dispersal type simulating animal treatment (intact buried seed; intact seed over the ground; partially preyed seed over the ground), each with five seeds, totaling 900 seeds. In the forest environment, an experiment was also conducted to verify the fate of seeds using the spool and line technique. The environment and the micro-habitat alone did not explain seed survival, although the dispersal type given by the animal disperser was significant for survival and the buried seeds were the only ones that survived until the last survey. With the spool and line seed experiment, we attested that most of the Paraná pine seeds were preyed after removal (81.5\%), and only buried seeds survived, reinforcing the role of scatterhoarding animals as important agents in the Paraná pine dispersal. This way, our results showed that Paraná pine seeds suffer a very high predation rate, and that only a few seeds escape from predators and recruiting (only $1.1 \%$ of the all seeds used in the two experiments), indicating that the survival of seeds is a critical step in the life cycle of this plant, highlighting the role of dispersal mode in recruiting success.

Keywords: seed dispersal patterns, Paraná pine, scatter-hoarding animals, seed predation. (1) .

\section{9} 0 


\section{Introduction}

Animal-plant interactions may suffer the influence of several factors, such as the season, environment characteristics, and the species involved in these interactions, and it can exert both negative (ex. seed predation) and positive (ex. seed dispersal) effects on plants reproduction success (Kersch and Fonseca 2005; Jordano et al. 2006; Soltani et al. 2018; Hernández-Brito et al. 2021). These processes are fundamental in the life cycle of plants and ultimately participate in the regulation and structuring of plant communities (Janzen 1971; Schupp et al. 2010). While seed predation can induce negative effects on predated plants (Gómez et al. 2003; Brocardo et al. 2018), seed dispersal is a mandatory process for permanence, regeneration, habitats colonization, and gene flow (Jansen et al. 2004, Zhu et al. 2019). This way, both are imperative for maintaining plant diversity in tropical forests (Vieira and Iob 2009; Villar et al. 2020).

According to the Janzel-Connell model the likelihood of seed survival is higher far from conspecific adults, but this model is mainly applied when the predators are invertebrates (Janzen 1970; Connell 1971). The lack of efficient seed dispersal mechanisms can generate competition between plants, affecting the survival and reproduction of individuals (Kula et al. 2020). However, even though since seed dispersal has singular importance for the dynamics of the animal and plant community, being a fundamental tool for understanding different levels of biological organization (individual, species, population, and landscape), it still remains as one of the less known biological processes (Musciano et al. 2020).

Zoochoric dispersal occurs between $50 \%$ to $90 \%$ of tropical tree species, evidencing animals' importance for plant recruitment (Francisco and Galetti 2001). Among the most singular forms of zoochoric dispersers are the scatter-hoarding animals (synzoochory), which are seed predators that commonly store seeds in branches or under the ground to survive periodic shortages of food (Smith and Reichman 1984; Vander Wall 2001). However, some of the hidden seeds end up not being recovered, presenting high germination rates since they are protected from desiccation, freezing, fire, pests, and predators (Forget 1990; Kollmann and Schill 1996; Jansen and Forget 2001; Gómez 2004; Lichti et al. 2017).

Scatter-hoarding mammals and birds usually store the seeds near logs, shrubs, and tree trunks (Pons and Pausas 2007; Ribeiro and Vieira 2016), which are likely used as visual landmarks for spatial memory (Barkley et al. 1998). Also, it is known that when plants are used as reference points, they may serve as nurse plants for seeds and seedlings, offering more favorable micro-habitats to the germination and recruitment of seedlings, facilitating their growth and development (Carlucci et al. 2011a; Carlucci et al. 2011b; Gómez-Aparicio et al. 2008; Padilla and Pugnaire 2006). These plants play a prominent role in the recovery of primary ecosystems, providing nutrients, 
91 water, protection from grazing, and trampling of seedlings (Ren et al. 2008; Gómez-Aparicio et al. 2008; Carlucci 92 et al. 2011a), and this process was verified for the Araucaria Forest, whose main element is the Paraná pine 93 (Araucaria angustifolia) and has expanded into pasture environments (Hueck 1953; Carlucci et al. 2011b). and this species is considered a key species, providing food for the regional fauna (Vieira and Iob 2009; Brum et al. 2010; Brocardo et al. 2018; Bogoni et al. 2020; Rosa et al. 2020). It presents large recalcitrant seeds (> $5 \mathrm{~g}$ ), locally named "pinhão", which need zoochoric dispersal to reach new environments (Soares and Mota 2004). And, even though its recruitment is strongly impacted by animals (Iob and Vieira 2008; Brocardo et al. 2018) this factor has received little attention in studies on the population dynamics of the species (Klein 1960; Souza et al. 2008; Paludo et al. 2016). Since the beginning of the 20th century the Paraná pine was heavily exploited for its valuable wood, reducing the current Araucaria Forest cover to only 12\% of the original area (Mähler-junior and Larocca 2009; Ribeiro et al. 2009). Today this species presents low regeneration in forest fragments and has been suffering from deforestation caused by the expansion of agriculture, biological invasions, and a high rate of predation on its seeds (Emer and Fonseca 2011; Brocardo et al. 2018).

There are two ways that the Paraná pine seed dispersal occurs, the first, when a predator accidentally drops the seed onto the ground during displacement, which can occur with parrots (Tella et al. 2016), monkeys

107 (CR Brocardo, obs. pers.), and small rodents (Brum et al. 2010; Vieira et al. 2011). The second is when scatter-

108 hoarding animals actively bury seeds in the soil as a form of food supply, such as the plush-crested jay (Cyanocorax 109 chrysops) (Uejima et al. 2012) and the green agouti (Dasyprocta azarae) (Brocardo et al. 2018). However, it is 110 not known yet how the different dispersal modes promoted by the animals and the places where they leave the 111 seeds can affect the successful establishment of the Paraná Pine (Vieira et al. 2001; Brum et al. 2010; Brocardo et 112 al. 2018). Tracking the seed's fate until germination or seed decay is a complicated process, as the scatter-hoarding 113 animals actively manage its caches, sometimes relocating the seeds (Jansen and Forget 2001; Vieira and Iob 2009). 114 In consequence, some studies focusing on the Paraná pine's seed dispersal were limited to evaluating only the first 115 path of the predation and removal process, without monitoring the seeds until their final destination (e.g. Iob and 116 Vieira 2008; Pereira and Ganade 2008; Brocardo et al. 2018; Brum et al. 2010). Studies related to seed dispersal provide necessary information for conservation biology, addressing the 118 different ecological and evolutionary processes (Musciano et al. 2020). The effectiveness of a disperser animal 119 species is directly linked to the contribution generated to the plant's future reproduction and is related to the number of dispersed seeds and the quality of this dispersal (Schupp 1993; Schupp et al. 2017). However, the qualitative 
121 aspects of the contributions of each disperser animal species and its effect on different environmental characteristics remain unclear for several species and ecosystems (Schupp 1993; Gómez 2004).

Acknowledging the importance of dispersal aspects for several critical ecology issues (Schupp et al. 2010), besides the fact that the Paraná pine is a threatened species (Thomas 2013), we aimed to evaluate the effect of seed dispersal mode (according to the disperser), the distance from adult conspecifics and the disposition site on recruitment success of Paraná pine. Our hypotheses were: Hypothesis 1. Scatter-hoarding is the most effective dispersal mode to establish Araucaria angustifolia. We predict that buried seeds have superior survival and germination rates when compared to seeds left above the ground. Hypothesis 2. The distant dispersal from conspecific adults is more important in open environments than in forest environments. We predict that the distance from conspecific adults does not follow the Janzen-Connell model of seed survival in a forest environment, due to the homogeneous presence of fauna inside the forest, however, in open areas, the predation rate should be highest near conspecific adults, due to the concentration of predators in these areas; Hypothesis 3. Nurse plants have a positive effect on the establishment of Araucaria angustifolia, especially in open environments. We predict that nurse plants positively influence seed germination by protecting the seed against dehydration.

\section{Material and methods}

Study area

The study was carried out in the Paulo Gorski Natural Municipality Park (2457'46.54"S, 5326'24.76"W) and Danilo Galafassi Natural Municipality Park (245 $\left.57^{\prime 2} 2^{\prime S}, 53^{\circ} 25^{\prime} 52^{\prime \prime W}\right)$, located in Cascavel, Paraná state, Brazil (24 $57^{\prime} 21$ "S, 53 $\left.27^{\prime} 19^{\prime \prime} \mathrm{W}\right)$, with an altitude of 730-780 meters above sea level, with a subtropical climate, characterized by the lack of a dry season and mean annual temperature of 19 to $21^{\circ} \mathrm{C}$ (Castella and Britez 2004) (Fig. 1). The study areas maintain together 110 ha of Araucaria Forest, where species responsible for most interactions with the Paraná pine seeds are found, such as the plush-crested jay (Cyanocorax chrysops), the black capuchin monkey (Sapajus nigritus), agouti (Dasyprocta azarae), rats (family Cricetidae) and parrots (family Psittacidae) (Pagno et al. 2015; Brocardo 2017; Brocardo et al. 2018).

\section{Experiment design}

\section{Effect of the environment, micro-habitat, and dispersal type on seed survival}

We simulated dispersal conditions that might occur naturally according to the environment (forest or open field), micro-habitats of dispersal disposition, and type of treatment given by the disperser animal, so we had the following experimental design (Fig. 2): 


\section{Environmental disposition}

- Forest (FT): in this environment, the seeds are dispersed both by scatter-hoarding animals (squirrels, agouti, jays) and by predators (monkeys, rats, parrots) (Brocardo et al. 2018).

- Open field (OF): environment outside the forest, where dispersal occurs mainly by jays and parrots, which use non-forest environments (Uejima et al. 2012; Tella et al. 2016).

\section{Dispersal micro-habitat}

- Under conspecific adult (UC): In this micro-habitat seeds left on the ground represent both the direct fall of the seeds and the action of animals foraging in the Paraná pine cones, causing the fall of seeds. Buried seeds below adults represent seeds stored at short distances (Jansen et al. 2004; Donatti et al. 2009) (see next section "Dispersal type done by disperser animal").

- Far from conspecific adults and next to a landmark (NL): this site attempts to simulate seed placement preference locations by scatter-hoarding animals, who use landmarks to resemble the cache location (Jansen 2003). We use trees other than the Paraná pine as reference. This disposal site, especially in the open field environment, can influence the success of seedling establishment since it provides a humid micro-habitat (Carlucci et al. 2011a). We used $30 \mathrm{~m}$ of distance from any female pine, considering the density and grouping of Paraná pine trees in the area (Brocardo et al. 2018).

- Far from conspecific adults and without a landmark (WL): seeds that have been carried a distance by predators or buried by scatter-hoarding animals. In this case, the seeds were made available at a minimum distance of $30 \mathrm{~m}$ from any female Paraná pine, considering the density and grouping of Paraná pine trees (Brocardo et al. 2018).

\section{Dispersal types done by the disperser animal}

- Intact seed over the ground (IS): simulating the dispersal by predators (monkeys, parrots, and rats) when they lose or abandon the entire seed during displacement (Iob and Vieira 2008; Vieira et al. 2011; Tella et al. 2016).

- Partially preyed seed over the ground (PS): simulating the dispersal by predators (rats and parrots), but in this case, the animal had already started consumption when the seed was abandoned (Vieira and Iob 2009; Tella et al. 2016). In this experiment, part of the seed was removed with a knife (30\%), not damaging the embryo, to allow the monitoring of germination (primary root tissue) and establishment of the seedling. 
- Intact buried seed (IB): at a depth of $5 \mathrm{~cm}$ simulating the dispersion made by scatter-hoarding animals (agouti, jay, and squirrel) (Brocardo et al. 2018).

In each environment (FT and OP) 30 sampling stations were established, 10 stations for each dispersal micro-habitat (UC, NL, and WL) (a list of abbreviations used in the text is available in the supplementary material, Table S5). The stations were located at least 30 meters from the other, a distance considered sufficient for sampling independence in seed removal studies (Chauvet and Forget 2005; Sanguinetti and Krizberger 2010). Each of them received five seeds of each dispersal type (IS, OS, IB), totaling 15 seeds per micro-habitat station, 450 per environment, summing 900 seeds in this experiment ( 2 environments x 30 micro-habitat sampling stations $\mathrm{x} 3$ treatments of dispersal type $\mathrm{x} 5$ seeds $=900$ seeds).

Seed fate experiment

Since the removal of seeds is frequently done over long distances, locating them becomes a difficult task, making it impossible to verify their fate. Thus, we conducted a parallel experiment in the forest environment, where we marked the seeds with the spool and line technique. This technique consists of attaching a spool of thread to each seed, which is drilled in the distal portion, not interfering with the germination probability (Donatti et al. 2009). A $20 \mathrm{~cm}$ steel line was passed through the perforations to prevent the animals from cutting the sewing line and subsequently connected (SI, Fig. S1, and S2). We used $90 \mathrm{~m}$ spools (100\% polyester thread), kept inside plastic jars (toothpick holder) to allow unwinding (SI, Fig. S1, and S2). To prevent dissection and fungi attack through the perforations, we used non-toxic white glue for sealing (SI, Fig. S1). It was not possible to repeat this experiment in the open field environment used in this survey since it has an elevated anthropic influence, with daily and constant use by people, which could cause the removal of lines or accidents. same dispersal type treatments (IS, PS, and IB), with the same number of replicates (five seeds in each), totaling 450 seeds. Thus, in our study, in total, 1350 Paraná pine seeds were used, being consistent with other studies that tested the effects of microhabitat and burial on the seed predation rates, such as studies with Quercus ilex and Quercus pyrenaica (1000 and 1600 seeds, respectively) (Gómez et al. 2003; Gómez 2004).

The seeds were selected using the floating technique (floating seeds were discarded) and by the visual inspection (larvae infestation) to attest germination viability (Doni Filho et al. 1985). We placed the seeds in the field in June 2019, during the maturation period of the Paraná pine seeds (autumn-winter), and we monitored them every 30 days to verify predation, removal, and recruitment. Follow-up continued for 120 days, when, probably, most of the seeds should have already germinated (Soares and Mota 2004). The identification of species that 
211 interact with the seeds in the second experiment was based on marks left by animals on the seeds after predation

212 (Müller 1986; Squinzani et al. 2021).

213 Statistical Analysis

214 We used the classic analysis of variance with repeated measures as statistical inference (RM-ANOVA), 215 followed by the corrective procedures by Geisser and Greenhouse (1958) and Huynh and Feldt (1976), GG and

$216 \mathrm{HF}$, respectively, for sphericity. As the survival data were measured in proportions of the initial value, the 217 transformation into arcsine of the square root was used, we also checked the conditions of normality and 218 homogeneity of variance in the residuals of the statistical model (Queen et al. 2002). With repeated measures 219 analysis of variance, it was possible to verify and compare results of different trials over time, analyzing the same 220 experimental unit over and over again (sensu Nobre and Singer 2007).

221 In the trial to evaluate the effects of the environment, micro-habitat, and type of dispersion, on the survival 222 of unmarked seeds, the complete three-factor RM-ANOVA was used for interactions up to third order. In the assay 223 with marked and unmarked seeds in the different treatments, survival was evaluated with complete two-factor RM224 ANOVA for interactions up to second order. The latter was also used to evaluate the effects of the types of 225 dispersers and micro-habitat on the survival of marked seeds.

\section{Results}

\section{Effects of the environment, micro-habitat, and dispersal type}

In the first experiment (unmarked seeds), from 900 seeds used to assess the effects of the environment, micro-habitat, and dispersal type, $11.8 \%$ were predated on the initial position site $(\mathrm{FT}=11.5 \%$ in and $\mathrm{OP}=12 \%)$, possibly by plush-crested jay (Cyanocorax chrysops), green agouti (Dasyprocta azarae), capuchin monkey

231 (Sapajus nigritus) and small rodents, based on the marks left on Paraná pine seeds (Squinzani et al. 2021) (SI -

232 Fig. S3). However, most of the seeds were removed from the site, corresponding to $87.3 \%$ of the total (FT=88.4\% 233 and $\mathrm{OF}=86.2 \%), 0.33 \%$ of the them remained intact without germinating until the last survey $(\mathrm{FT}=0 \%$ and $\mathrm{OF}=$ $2340.66 \%), 0.11 \%$ became unviable due to decay $(\mathrm{FT}=0 \%$ and $\mathrm{OF}=0.22 \%$ ) and only $0.44 \%$ germinated until the 235 last survey $(\mathrm{FT}=0 \%$ and $\mathrm{OF}=0.88 \%)$. Although the final survival rate was higher in the open field $(\mathrm{OF})$, the 236 environment was not significant $(\mathrm{F}=0.37, \mathrm{p}=0.53)$.

The micro-habitat (seed dispersal site), as well as the environment, did not explain the seed survival alone

$238(\mathrm{~F}=0.67, \mathrm{p}=0.51)$. On the other hand, the dispersal type provided by the disperser was significant for survival $239(\mathrm{~F}=10.87, \mathrm{p}<0.001)$, and the buried seeds were the only ones that survived until the last survey (Fig. 3). In the open 240 field (OF) area, buried seeds (IB) far from conspecific adults and next to a landmark (NL) (n=50) presented $8 \%$ of 
241 germination, which is equivalent to $0.88 \%$ of all seeds in this environment $(n=450)$, or $0.44 \%$ of the total $(n=900)$.

242 Still, $4 \%$ of OF-NL-IB seeds (initial $n=50)$ and $2 \%$ of OF-UC-IB $(n=50)$ remained possibly viable, but they did

243 not germinate, totaling $0.66 \%$ of the seeds in open fields $(n=450)$, or $0.33 \%$ of all seeds $(n=900)$. This resulted in

244 a significant interaction between environment and micro-habitat $(F=3.78, p=0.02)$, indicating that seeds in open

245 fields, far from conspecific adults, and next to landmarks are more likely to survive.

246 The highest animal-seed interaction rates occurred in the first survey, after 30 days of initial disposal,

247 with $89.5 \%$ of the total, when the largest number of seeds were removed and predated, both in the open field (OF

$248=88.6 \%)$ and in forest $(\mathrm{FT}=90.6 \%)$, which resulted in a significant response for the time factor (Table 1: $\mathrm{F}=20.63$,

$249 \mathrm{p}<0.001, \mathrm{p}[\mathrm{GG}]<0.001, \mathrm{p}[\mathrm{HF}]<0.001)$. The interaction of time factor and dispersal type was also significant $250(\mathrm{~F}=8.13, \mathrm{p}<0.001, \mathrm{p}[\mathrm{GG}]=0.08, \mathrm{p}[\mathrm{HF}]<0.001)$, indicating that buried seeds (IB) survived for a longer time (SI,

251 Fig. S4); as well as the interaction time, environment and dispersal type, which was significant ( $F=4.84, p<0.001$, $252 \mathrm{p}[\mathrm{GG}]<0.01, \mathrm{p}[\mathrm{HF}]<0.004)$, driven by the higher survival of buried seeds (IB) in the open field (OF) (Fig. 3ab). 253 Finally, significance was observed in the triple interaction between the environment, micro-habitat, and time $254(\mathrm{~F}=3.62, \mathrm{p}=0.001, \mathrm{p}[\mathrm{GG}]=0.01, \mathrm{p}[\mathrm{HF}]=0.01)$, in which the seeds disposed in the open field $(\mathrm{OF})$, far from 255 conspecific adults and next to landmark (NL), and buried (IB), survived for a longer period (Fig. 3cd). Seed fate experiment

The information obtained from the seeds marked in the forest concerning the dispersal types corroborates with the results obtained from the test with unmarked seeds, as a significant effect of the interaction between the dispersal type and time was observed (RM_ANOVA: $F=12.71, p<0.0001, p(G G)<0.0001, p(H F)<0.0001)$, in which intact buried seed (IB) survived longer (Fig. 5), regardless of micro-habitat (RM_ANOVA, microhabitat*time: $\mathrm{F}=1.01, \mathrm{p}=0.42, \mathrm{p}(\mathrm{GG} 0.40, \mathrm{p}(\mathrm{HF})=0.40)$.

The Paraná pine seeds marked with spool and line followed the same pattern as the unmarked seeds, having the highest interaction rates with animals during the first survey (30 days after the placement of the seeds).

264 In this phase, $64.9 \%$ of seeds were predated, while $8.8 \%$ were stocked, $14 \%$ had not been removed from the 265 disposal sites, and $12.2 \%$ were removed, but due to line breakage it was not possible to reach the destination. Up 266 to the last survey $81.5 \%$ of the seeds had been predated and $14.6 \%$ were removed but lost due to broken lines (Fig. $2674)$.

There was only one secondary storage in the 60-day survey, without storage in the other reads and, therefore, the number of stored seeds did not change from the first survey to the others. The average distance of the storage locations in relation to the initial position of the seeds was only $2.81 \mathrm{~m}$, ranging from zero (buried in 
271 the initial position) to $13.8 \mathrm{~m}$.

272 Intact buried seeds (IB) in their initial position were the only ones to germinate, that occurred in the third 273 and fourth surveys (90 and 120 days respectively), representing $1.33 \%$ of the total, although just $0.88 \%$ survived 274 until the end of the experiment (SI, Table S4). Possibly viable Paraná pine seeds that had not germinated yet totaled $2751.77 \%$, mostly corresponding to intact buried seeds $(\mathrm{IB}=1.54 \%)$, and only one seed $(0.22 \%)$ removed and stored 276 by an animal. Some seeds also had mortality linked to other causes, such as dehydration and rot, totaling $1.11 \%$.

277 From the predated seeds the main responsibles were the Plush-crested jays (Cyanocorax chrysops) 278 (39.56\% of the seeds), small rodents (22.67\%), the green agouti (Dasyprocta azarae) (16\%), and insects attacked $2791.33 \%$ of seeds (SI, Fig. S3).

When comparing marked and unmarked seeds in the forest environment (FT) no interactive effect of 281 marking was identified over the experimental days (RM-ANOVA: $\mathrm{F}(3,24)=1.62, \mathrm{p}=0.21$ ), but we observed an 282 effect for marking (RM-ANOVA: $\mathrm{F}(1,8)=11.89, \mathrm{p}=0.009$ ), in which the spool and line technique obtained 283 higher survival at all times sampled. Unmarked Paraná pine seeds were preferentially selected by the animals, 284 decreasing their survival compared to labeled seeds from the first reading to 30 days (Fig. 6). The interaction 285 between treatments and time was also significant (RM-ANOVA: $F(24,24)=3.02, p=0.004$; GG: e = 0.4146, p $286=0.048 ; \mathrm{HF}: \mathrm{e}=0.4567, \mathrm{p}=0.040$ ), with faster removal of seeds left over the ground, especially in relation to PS 287 that were all removed and preyed on the first reading (95\% predated and 5\% removed without destination 288 registration).

\section{Discussion}

The removal rate of Paraná pine seeds by animals was high in both experiments and the marking 291 experiment attested that most of the seeds suffered predation after removal, which was probably the same fate of 292 seeds removed in the first experiment. This result can be linked to several factors, such as the attractiveness of 293 large seeds with high energetic value and their maturation in a food scarcity period, serving as a key resource for 294 fauna during Winter (Vieira and Iob 2009; Brocardo et al. 2018; Bogoni et al. 2020; Rosa et al. 2020). The very 295 high seed predation rate that we have recorded, with only $1.1 \%$ of the seeds reaching germination, corroborates 296 that the seed survival from predators is a critical stage in the life cycle of the Paraná pine (Paludo et al. 2016, 297 Brocardo et al. 2018; Rosa et al. 2020), highlighting the role of dispersal type in the recruiting success. In this sense, storage was the most successful type of dispersal, validating hypothesis I, with buried seeds 299 presenting higher survival and germination rates for A. angustifolia. This result can be explained by the protection that buried seeds have against predators (Gómez 2004; Lichti et al. 2017; Brocardo et al. 2018; Martínez-Baroja 
301 et al. 2021) and by the better moisture conditions (Forget 1990; Kollmann and Schill 1996), demonstrating the importance of the relationship between scatter-hoarding animals and the Paraná pine. Despite that, the spool and

303 line experiment revealed that only $0.2 \%$ of the seeds stored by animals $(9,1 \%)$ survived to secondary dispersal during the experiment. Overall, plants that are dispersed by scatter-hoarding animals suffer high seed predation rates, as evidenced for Bertholletia excelsa, with scatter-hoarding rodent recovery up to $99.4 \%$ of cached seeds (Haugaasen et al. 2010). In another example, for Carapa procera, a tropical tree that is also dispersed by scatterhoarding animals, the establishment of seedlings was less than $1 \%$ of the seeds available to the animals, ranging from $0.7 \%$, in a year of high seed production, to only $0.1 \%$ in low production years (Jansen et al. 2004). Most scatter-hoarding animals are well suited for retrieving their hiding places relying on spatial memory and olfactory cues (Vander Wall 2000), estimates of scatter-hoarding retrieval by squirrels and other small mammals often 311 exceed 90\% (Steele et al. 2005). Additionally, environmental conditions can determine the quantity and quality of seed storage and this can be decisive for the recovery (Jansen and Forget 2001). The high olfactory capacity of

313 rodents increases the chances to recover cached seeds, being these post-dispersal interactions a critical stage to the recruitment effectiveness of nut-producing trees (Haugaasen et al. 2010; Elwood et al. 2017).

On the other hand, seeds left above the ground did not present survival. Partially predated seeds, simulating dispersal provided by rats and parrots (Tella et al. 2016), were the first to be predated and removed. In

317 the experiment with marked seeds, it was possible to verify that almost all of them were preyed during the first survey (30 days). These results indicated that parrots and rats partially prey on seeds and abandon them, and even

319 if they do not affect the embryo, have little efficiency as dispersers. Entire Paraná pine seeds left above the ground, simulating the dispersal by predators (monkeys, parrots, and rats) when they lose or abandon the entire seed during movement (Iob and Vieira 2008; Vieira et al. 2011; Tella et al. 2016), also had little success, probably due to the exposure to predators.

The micro-habitat, which represented sites where seeds may be dispersed, did not explain survival alone, although it was significant in interaction with the environment, with higher seed survival rates far from conspecific adults and next to a landmark in the open field, corroborating with the hypothesis 2 . As expected, the distance from conspecific adults did not result in higher survival rates in FT, due to the homogeneous presence of the fauna

327 (Brocardo et al. 2018), indicating that predation did not follow the Janzen-Connell model, which postulates a higher chance of seed survival far from conspecific adults (Janzen 1970; Connell 1971). The UC microhabitat presented longer survival than the other microhabitats at the 30-day survey, a similar pattern observed for Virola 
331 below reproductive adults can generate more satiety to predators, delaying seed removal (Vander Wall 2002; Iob and Vieira 2008; Xiao et al. 2013). The opposite result was observed in OF, where the predation rate was superior under conspecific (UC), probably in response to the concentration of predators in these areas (Gómez et al. 2003; Gómez 2004; Sanguinetti and Kitzberger 2009).

In the OF, the greatest survival was observed in seeds far from conspecific adult next to landmark, corroborating hypothesis 3 . This form of storage in an OF in our study environment reflects the behavior of 337 Cyanocorax chrysops, which as other corvids use landmarks as a reference to spatial memory (Balda and Kamil 2006). Landmark trees then function as nurse plants providing a favorable environment for germination (GómezAparicio et al. 2008; Carlucci et al. 2011b), which may contribute to Paraná pine expansion in open areas. The expansion of A. angustifolia over grasslands has been seen as characteristic of a restrict and pioneer heliophile species (Klein 1960), although young plants tolerate shading (Duarte and Dillenburg 2000; Duarte et al. 2002; Sanguinetti 2014; Brocardo et al. 2018), indicating light demand is not responsible to the low recruitment in the

343 forest. Our results indicate the high regeneration in open and border areas could be associated with higher seed 344 survival, due to the lower abundance of predators, corroborating previous studies (Lamberts 2003; Brum et al. 345 2010). Thus, expansion over open areas would reflect an escape from predation rather than a response to the 346 demand for light.

\section{Conclusion}

For the Paraná pine, which relies its seed dispersal on seed predators, the success of establishment is

349 strictly linked to the way and location where the seeds are placed, and their density in the environment. Among 350 the animals that can disperse Paraná pine seeds, scatter-hoarding animals are probably more effective for survival 351 and germination of seeds, as they cache the seeds, decreasing the chances that other animals found them, in 352 addition, cached seeds have better conditions to recruit. In the open field the micro-habitat of seed deposition can 353 also influence the germination efficiency, especially those that have the action of nurse plants. The processes of 354 predation and seed dispersal of Paraná pine are largely responsible for the successful recruitment of the species, 355 being probably one of the most important phases of its life cycle, which should be taken into account in recovery 356 plans and conservation of the Araucaria Forest.

\section{References}

358 Amarante CVT, Mota CS, Megguer CA, Ide GM (2007) Conservação pós-colheita de pinhões [sementes de 359 Araucaria angustifolia (Bertoloni) Otto Kuntze] armazenados em diferentes temperaturas. Ciência Rural $360 \quad 37: 2: 346-351$ 
361 Balda RP, Kamil AC (2006) Linking life zones, life history traits, ecology, and spatial cognition in four

362 allopatric southwestern seed caching corvids. In: Brown MF, Cook RG (eds) Animal spatial cognition:

363 comparative, neural, and computational approaches. http://www.pigeon.psy.tufts.edu/asc/balda/

364 Barkley CL, Jacobs LF (1998) Visual environment and delay affect cache retrieval accuracy in a food-storing

365 rodent. Animal Learning \& Behavior 26:4:439-447.

366 Bogoni JA, Muniz-Tagliari M, Peroni N, \& Peres CA (2020) Testing the keystone plant resource role of a

367 flagship subtropical tree species (Araucaria angustifolia) in the Brazilian Atlantic Forest. Ecological Indicators

$368118: 106778$.

369 Brocardo CR (2017) Defaunação e fragmentação florestal na Mata Atlântica Subtropical e suas consequências

370 para a regeneração de Araucaria angustifolia. Tese (Doutorado em Ciências Biológicas - Zoologia) - Instituto de

371 Biociências, Universidade Estadual Paulista, Rio Claro.

372 Brocardo CR, Pedrosa F, Galetti M (2018) Forest fragmentation and selective logging affect the seed survival

373 and recruitment of a relictual conifer. Forest Ecology and Management 408:87-93.

374 Brum F, Duarte L, Hartz S (2010) Seed removal patterns by vertebrates in different successional stages of

375 Araucaria forest advancing over southern Brazilian grasslands. Community Ecology 11:35-40.

376 Carlucci MB, Duarte LS, Pillar VD (2011) Nurse rocks influence forest expansion over native grassland in

377 southern Brazil. Journal of Vegetation Science 22:111-119. a

378 Carlucci MB, Teixeira F, Brum F, Duarte L (2011) Edge expansion of Araucaria forest over southern Brazilian

379 grasslands relies on nurse plant effect. Community Ecology 12:196-201. b

380 Castella PR, Britez RM (2004) A floresta com araucária no Paraná: conservação e diagnóstico dos

381 remanescentes florestais. Brasília: Fundação de Pesquisas Florestais do Paraná. Brasília: Ministério do Meio

382 Ambiente 236.

383 Chauvet S, Forget PM (2005) Edge effects on post-dispersal seed removal in a fragmented rain forest in French

384 Guiana. Journal of Tropical Ecology 21:01:113-116.

385 Connell JH (1971) On the role of natural enemies in preventing competitive exclusion in some marine animal

386 and in rain forest trees. In: Den Boen, P.J.; Gradwell, P.R. (eds.). Dynamics of populations. Pudoc, Wageningen

$387 \quad 298-312$.

388 Donatti CI, Guimarães JR PR, Galetti M (2009) Seed dispersal and predation in the endemic Atlantic rainforest

389 palm Astrocaryum aculeatissimum across a gradient of seed disperser abundance. Ecological Research 6:1187-

3901195. 
391 Doni Filho L, Amaral L, Cervi PH (1985) Métodos para testar o poder germinativo das sementes de Araucaria angustifolia (Bert) O. Ktze. Revista Brasileira de Sementes 7:2:113-124.

393 Duarte LDS, Dillenburg LR (2000) Ecophysiological responses of Araucaria angustifolia seedlings to different 394 irradiance levels. Australian Journal of Botany 48:4:531-537.

395 Duarte LDS, Dillenburg LR, Rosa LMG (2002) Assessing the role of light availability in the regeneration of 396 Araucaria angustifolia (Araucariaceae). Australian Journal of Botany 50:741-751.

397 Elwood EC, et al. (2017) Scatterhoarders drive long- and short-term population dynamics of a nutproducing tree, 398 while pre-dispersal seed predators and herbivores have little effect. Journal of Ecology 0:0:1-13.

399 Emer C, Fonseca CR (2011) Araucaria Forest conservation: mechanisms providing resistance to invasion by 400 exotic timber trees. Biological Invasions 13:189-202.

401 Francisco MR, Galetti M (2001) Frugivoria e dispersão de sementes de Rapanea lancifolia (Myrsinaceae) por 402 aves numa área de cerrado no Estado de São Paulo, sudeste do Brasil. Ararajuba 9:1:13-19.

403 Forget PM (1990) Seed-dispersal of Vouacapoua americana (Caesalpiniaceae) by caviomorph rodents in French 404 Guiana. Journal of Tropical Ecology 6:04:459-468. doi:10.1017/s0266467400004867

405 Forget PM, et al. (2000) Effects of Dispersal Pattern and Mammalian Herbivores on Seedling

406 Recruitment for Virola michelii (Myristicaceae) in French Guiana. Biotropica 32:3:452-462.

407 Galetti M (2006) Seed survival and dispersal of an endemic Atlantic forest palm: The combined effects of 408 defaunation and forest fragmentation. Botanical Journal of the Linnean Society 15:141-149.

409 Geisser S, Greenhouse SW (1958). An extension of box's results on the use of the \$ F \$ distribution in 410 multivariate analysis. Annals of Mathematical Statistics 29:3:885-891.

411 Gómez-Aparicio L, et al. (2008) Facilitation of tree saplings by nurse plants: Microhabitat amelioration or 412 protection against herbivores? Journal of Vegetation Science 19:2:161-172. doi:10.3170/2008-8-18347

413 Gómez JM, García D, Zamora R (2003) Impact of vertebrate acorn- and seedling-predators on a Mediterranean 414 Quercus pyrenaica forest. Forest Ecology and Management 180:125-134.

415 Gómez JM (2004) Importance of microhabitat and acorn burial on Quercus ilex early recruitment: non-additive 416 effects on multiple demographic processes. Plant Ecology 172:287-297.

417 Google pictures (2021). Araucaria angustifolia.

418 https://www.google.com/search?q=araucaria+angustifolia\&sxsrf=AOaemvLJ4D7grWB2sREtbdXIZT0YW2isjQ

419 :1632246322527\&source=Inms\&tbm=isch\&sa=X\&ved=2ahUKEwjZsvWxz5DzAhUOIrkGHd6mAOkQ_AUoA 420 XoECAEQAw\&biw=1366\&bih=657\&dpr=1. Accessed 10 June 2021. 
421 Haugaasen JMT, et al. (2010) Seed dispersal of the Brazil nut tree (Bertholletia excelsa) by scatter-hoarding

422

423

424

425

426

427

428

429

430

431

432

433

434

435

436

437

438

439 conservação.

443 Kersch MF, \& Fonseca CR (2005) Abiotic factors and the conditional outcome of an ant-plant mutualism.

444 Ecology 86:8:2117-2126.

445 Klein RM (1960) O aspecto dinâmico do pinheiro brasileiro. Sellowia 12:17-44.

446 Kollmann J, Schill HP (1996) Spatial patterns of dispersal, seed predation and germination during colonization

447 of abandoned grassland by Quercus petraea and Corylus avellana. Vegetatio 125:2:193-205. doi:10.1007/bf00044651

449 Kula AAR, Hey MH, Couture JJ et al. (2020) Intraspecific competition reduces plant size and quality and damage severity increases defense responses in the herbaceous perennial, Asclepias syriaca. Plant Ecology 
https://doi.org/10.1007/s11258-020-01021-4.

452 Lamberts AVDH (2003) Predação e sobrevivência de sementes de Araucaria angustifolia [Bert.] 0. Ktze em

453 áreas de mata nativa e plantações de Pinus eliotti na Floresta Nacional de São Francisco de Paula, RS.

454 Dissertation, Universidade Estadual de Campinas.

455 Lichti NI, Steele MA, Swihart RK (2017) Seed fate and decision-making processes in scatter-hoarding rodents.

456 Biological Reviews 92:474-504.

457 Mähler-junior JKF, Larocca JF (2009) Fitofisionomias, desmatamento e fragmentação da Floresta com

458 Araucária. In: Fonseca CR, Souza AF, Leal-Zanchet AM, Dutra T, Backes A, Ganado G. Floresta com

459 Araucária: Ecologia, conservação e desenvolvimento sustentável. Ribeirão Preto, SP, Holos. pp. 243-252.

460 Mantovani A, Morellato LPC, Dos Reis MS (2004) Fenologia reprodutiva e produção de sementes em Araucaria

461 angustifolia (Bert.) O. Kuntze. Revista brasileira de botânica 27:4:787-796.

462 Martínez-Baroja L, Pérez-Camacho L, Villar-Salvador P, Rebollo S, Leverkus AB, Pesendorfer MB, Molina-

463 Morales M, Castro J, \& Rey-Benayas JM (2021) Caching territoriality and site preferences by a scatter-hoarder

464 drive the spatial pattern of seed dispersal and affect seedling emergence. Journal of Ecology 00:1:12 doi:

$465 \quad 10.1111 / 1365-2745.13642$

466 Mattos PP et al. (2007) Crescimento de Araucaria angustifolia na Reserva Florestal Embrapa Epagri, Caçador,

467 SC. Pesquisa Florestal Brasileira 55:107-114.

468 Mattos JRD (2011) O pinheiro brasileiro. Florianópolis, Santa Catarina.

469 Müller JA (1986) A influência dos roedores e aves na regeneração da Araucaria angustifolia [Bert.] 0. ktze.

470 Curitiba, 1986. 77 f. Dissertação (Pós-Graduação em Engenharia Florestal) - Setor de Ciências Agrárias,

471 Universidade Federal do Paraná.

472 Musciano Di, Di Cecco M, Bartolucci V et al. (2020) Dispersal ability of threatened species affects future

473 distributions. Plant Ecology doi:10.1007/s11258-020-01009-0.

474 Nobre JS, Singer, JM (2007) Residuals analysis for linear mixed models. Biometrical Journal 49:6:863-875.

475 Padilla FM, Pugnaire FI (2006) The role of nurse plants in the restoration of degraded environments. Frontiers in

476 Ecology and the Environment 4:196-202.

477 Pagno L, Cândido JFJ, Brocardo CR (2015) Seed predation of Araucaria angustifolia by Sapajus nigritus.

478 Neotropical Primates 22:1:1-6.

479 Paludo GF, et al. (2016) Inferring population trends of Araucaria angustifolia (Araucariaceae) using a transition 480 matrix model in an old-growth forest. Southern Forests 78:2:137-143. 
481 Pereira F, Ganade G (2008) Spread of a Brazilian keystone-species in a landscape mosaic. Forest Ecology and

482 Management 255:1674-1683. doi:10.1016/j.foreco.2007.11.026

483 Pons J, Pausas JG (2007) Acorn dispersal estimated by radio-tracking. Oecologia 153:903-911.

484 Queen JP, Quinn GP, Keough MJ (2002). Experimental design and data analysis for biologists. Cambridge 485 university press.

486 Ren H, Yang L, Liu N (2008) Nurse plant theory and its application in ecological restoration in lower subtropics 487 of China. Progress in Natural Science 18:137-142.

488 Ribeiro MC, et al. (2009) The Brazilian Atlantic Forest: How much is left, and how is the remaining forest 489 distributed? Implications for conservation. Biological Conservation 142:1141-1153.

490 Ribeiro JF, Vieira EM (2016) Microhabitat selection for caching and use of potential landmarks for seed

491 recovery by a neotropical rodent. Journal of Zoology 1:7.

492 Rosa C, Hegel CGZ, Passamani M (2020) Seed removal of Araucaria angustifolia by native and invasive 493 mammals in protected areas of Atlantic Forest. Biota Neotropica 21:1:1-6. doi: 10.1590/1676-0611-bn-2020-

$494 \quad 1111$

495 Sanguinetti J, Kitzberger T (2009) Efectos de la producción de semillas y la heterogeneidad vegetal sobre la

496 supervivencia de semillas y el patrón espacio-temporal de establecimiento de plántulas en Araucaria araucana.

497 Revista Chilena de Historia Natural 82:3. doi:10.4067/s0716-078x2009000300001

498 Sanguinetti J, Kitzberger T (2010). Factors controlling seed predation by rodents and non-native Sus scrofa in 499 Araucaria araucana forests: potential effects on seedling establishment. Biological Invasions 12:3:689-706.

500 Sanguinetti J (2014) Producción de semillas de Araucaria araucana (Molina) K. Koch durante 15 años en

501 diferentes poblaciones del Parque Nacional Lanín (Neuquén-Argentina). Ecologia Austral 24:265-275.

502 Smith CC, Reichman OJ (1984) The evolution of food caching by birds and mammals. Annual Review of

503 Ecology and Systematics 15.1: 329-351.

504 Schupp EW (1993) Quantity, quality and the effectiveness of seed dispersal by animals. Vegetatio 107:15-29.

505 Schupp EW, Jordano P, Gómez J.M (2010) Seed dispersal effectiveness revisited: a conceptual review. New 506 Phytologist 188:333-353.

507 Schupp EW, Jordano P, Gómez JM (2017) A general framework for effectiveness concepts in mutualisms.

508 Ecology Letters doi: 10.1111/ele.12764.

509 Soares TS, Mota JH (2004) Araucária - O Pinheiro do Paraná. Revista Científica

510 e Eletrônica de Engenharia Florestal 2:3:1-8. 
511 Soltani E, Baskin CC, Baskin JM, Heshmati S, Mirfazeli MS (2018) A meta-analysis of the effects of frugivory

512 (endozoochory) on seed germination: role of seed size and kind of dormancy. Plant Ecology

513 doi:10.1007/s11258-018-0878-3

514 Souza AF, Forgiarini C, Longhi SJ, Brena DA (2008) Regeneration patterns of a long-lived dominant conifer

515 and the effects of logging in southern South America. Acta Oecologica 34:221-232.

516 Squinzani LI, Piana PA, Brocardo CR (forthcoming) Padrões de predação da semente do pinheiro-do-paraná

517 (Araucaria angustifolia).

518 Steele M, Wauters LA, Larsen KW (2005) Selection, Predation and Dispersal of Seeds by Tree Squirrels in

519 Temperate and Boreal Forests: are Tree Squirrels Keystone Granivores? In: Forget PM, Lambert JE, Hulme PE,

520 Vander Wall SB (ed) Seed Fate. CABI Publishing. Cambridge/Oxfordshire, 205-221.

521 Tella JL, et al. (2016) Endangered plant-parrot mutualisms: seed tolerance to predation makes parrots pervasive

522 dispersers of the Parana pine. Scientific Reports 6:1-11.

523 Thomas P (2013) Araucaria angustifolia. The IUCN Red List of Threatened Species 2013: e.T32975A2829141.

524 https://dx.doi.org/10.2305/IUCN.UK.2013-1.RLTS.T32975A2829141.en. Downloaded on 18 April 2021.

525 Uejima AMK, Boesing AL, Anjos LD (2012) Breeding and Foraging Variation of the Plush-Crested Jay

526 (Cyanocorax chrysops) in the Brazilian Atlantic Forest. The Wilson Ornithological Society 124:1:87-95.

527 Vander Wall SB (2000) The influence of environmental conditions on cache recovery and cache pilferage by

528 yellow pine chipmunks (Tamias amoenus) and deer mice (Peromyscus maniculatus). Behavioral ecology

$529 \quad 11: 5: 544-549$.

530 Vander Wall SB (2001) The Evolutionary Ecology of Nut Dispersal. The Botanical Review 67:1:74-117.

531 Vander Wall SB (2002) Masting in animal-dispersed pines facilitates seed dispersal. Ecology 83:3508-3516.

532 Vieira EM, Iob G (2009) Dispersão e predação de sementes da araucária (Araucaria angustifolia). Floresta de

533 Araucária: Ecologia, Conservação e Desenvolvimento Sustentável 85-95.

534 Vieira EM, Ribeiro JF, Iob G (2011) Seed predation of Araucaria angustifolia (Araucariaceae) by small rodents

535 in two areas with contrasting seed densities in the Brazilian Araucaria forest. Journal of Natural History 45:13-

$536 \quad 14: 843-854$.

537 Villar N, Siqueira T, Zipparro V, et al. (2020) The cryptic regulation of diversity by functionally complementary

538 large tropical forest herbivores. Journal of Ecology 108: 279-290. DOI: 10.1111/1365-2745.13257 
539 Xiao Z, Zhang Z, \& Krebs CJ (2013) Long-term seed survival and dispersal dynamics in a rodent-dispersed tree:

540 testing the predator satiation hypothesis and the predator dispersal hypothesis. Journal of Ecology 101:5:1256-

541 1264. DOI: $10.1111 / 1365-2745.12113$

542 Zhu J, et al. (2019) A trade-off between primary and secondary seed dispersal by wind. Plant Ecology.

543 DOI:10.1007/s11258-019-00934-z

544

545

546

547

548

549

550

551

552

553

554

555

556

557

558

559

560

561

562

563

564

565

566

567

568 
569 Table 1 Results of classical repeated-measure of three-factor analysis of variance for Paraná pine seed survival

570 (data transformed into arcsine square root). The test statistics $(\varepsilon)$ and probabilities obtained by the corrective

571 procedures for sphericity of Geisser and Greenhouse (1958) and Huynh and Feldt (1976), p(GG) and p(HF),

572 respectively, are presented. Values in bold indicate significant effects $(\mathrm{p}<0.05)$. For the effects involving time,

573 only those significant in the three tests (p, p(GG) and $\mathrm{p}(\mathrm{HF}))$ were interpreted.

\begin{tabular}{|c|c|c|c|c|}
\hline \multicolumn{3}{|l|}{ Explanatory variable } & \multirow{2}{*}{$\begin{array}{c}\varepsilon=0.440 \\
p(G G)\end{array}$} & \multirow{2}{*}{$\begin{array}{c}\varepsilon=0,442 \\
p(H F)\end{array}$} \\
\hline & $\mathbf{F}$ & $\mathbf{p}$ & & \\
\hline Environment & 0.3794 & 0.5388 & & \\
\hline Micro-habitat & 0.6709 & 0.5127 & & \\
\hline Dispersal & 10.8722 & $<0.0001$ & & \\
\hline Environment: Micro-habitat & 3.7825 & 0.0248 & & \\
\hline Environment: Dispersal & 0.2219 & 0.8013 & & \\
\hline Micro-habitat: Dispersal & 0.4976 & 0.7375 & & \\
\hline Environment: Micro-habitat: Dispersal & 1.9234 & 0.1090 & & \\
\hline Time & 20.6329 & $<0.0001$ & 0.0008 & $<0.0001$ \\
\hline Environment: Time & 0.2446 & 0.8652 & 0.6881 & 0.6893 \\
\hline Micro-habitat: Time & 0.1845 & 0.9811 & 0.8856 & 0.8864 \\
\hline Dispersal: Time & 8.1390 & $<0.0001$ & 0.0851 & 0.0001 \\
\hline Environment: Micro-habitat: Time & 3.6255 & 0.0016 & 0.0179 & 0.0177 \\
\hline Environment: Dispersal: Time & 4.8440 & 0.0001 & 0.0042 & 0.0041 \\
\hline Micro-habitat: Dispersal: Time & 0.6650 & 0.7854 & 0.6587 & 0.6595 \\
\hline Micro-habitat: & 1.2743 & 0.2302 & 0.2745 & 0.2744 \\
\hline
\end{tabular}


List of Figures

582 Fig. 1 Location of Cascavel in Paraná state, Brazil, highlighting the study areas: Danilo Galafassi Natural

583 Municipality Park "A", Paulo Gorski Natural Municipality Park "B" and their corresponding sampling stations.

584 UC: under conspecific adults, NL: far from conspecific adults and next to landmark, WL far from adults and 585 without landmark.

586 Fig. 2 Representation of the experimental design that has eighteen treatments, formed by the factorial arrangement 587 of two disposition environments (FT and OF) with three types of micro-habitat sites (UC, WL, and NL) and three 588 dispersal types (PS, IS, and IB). Data collection contained four replicates of 30 days, 60 days, 90 days, and 120 589 days.

590 Fig. 3 Survival (proportion of non-predated and possibly viable seeds) of Paraná pine seeds, categorized by 591 dispersal types (IB= intact buried seed; IS= intact seed over the ground; $\mathrm{PS}=$ partially preyed seed over the ground), 592 observed in the open field (a) and in the forest (b); and categorized by micro-habitats of dispersion (UC= under 593 conspecific adult; $\mathrm{NL}=$ far from conspecific adults and next to landmark; WL= far from conspecific adult and 594 without landmark), observed in the open field (c) and in the forest (d). Bars indicate standard error, estimated on 595 data transformed to arcsine square root and converted back to proportion. In it, it is possible to verify differences 596 in survival, being more effective the open environment with the micro-habitat far from conspecific adults and next 597 to landmark and the intact buried seed treatment.

598 Fig. 4 Destination of seeds marked in FT environment in the dispersal types (PS, IS and IB) in 3 types of micro599 habitat (UC, WL and NL). The sampling contains 4 replicates of 30, 60, 90 and 120 days.

600 Fig. 5 Survival (proportion of non-predated and possibly viable seeds) of Paraná pine seeds in relation to types of 601 dispersion (IB = intact buried seed; IS = intact seed over the ground; PS = partially preyed seed over the ground) 602 throughout the experimental days. Bars indicate standard error, estimated on data transformed to arcsine square 603 root and converted back to proportion. IB was more effective in the survival of the seeds.

604 Fig. 6 Survival (proportion of non-predated and possibly viable seeds) of Paraná pine seeds with and without 605 marks for tracking throughout the experimental days. Bars indicate standard error, estimated on data transformed 606 to arcsine square root and converted back to proportion. Seeds with marking had greater survival at all times 607 sampled. 

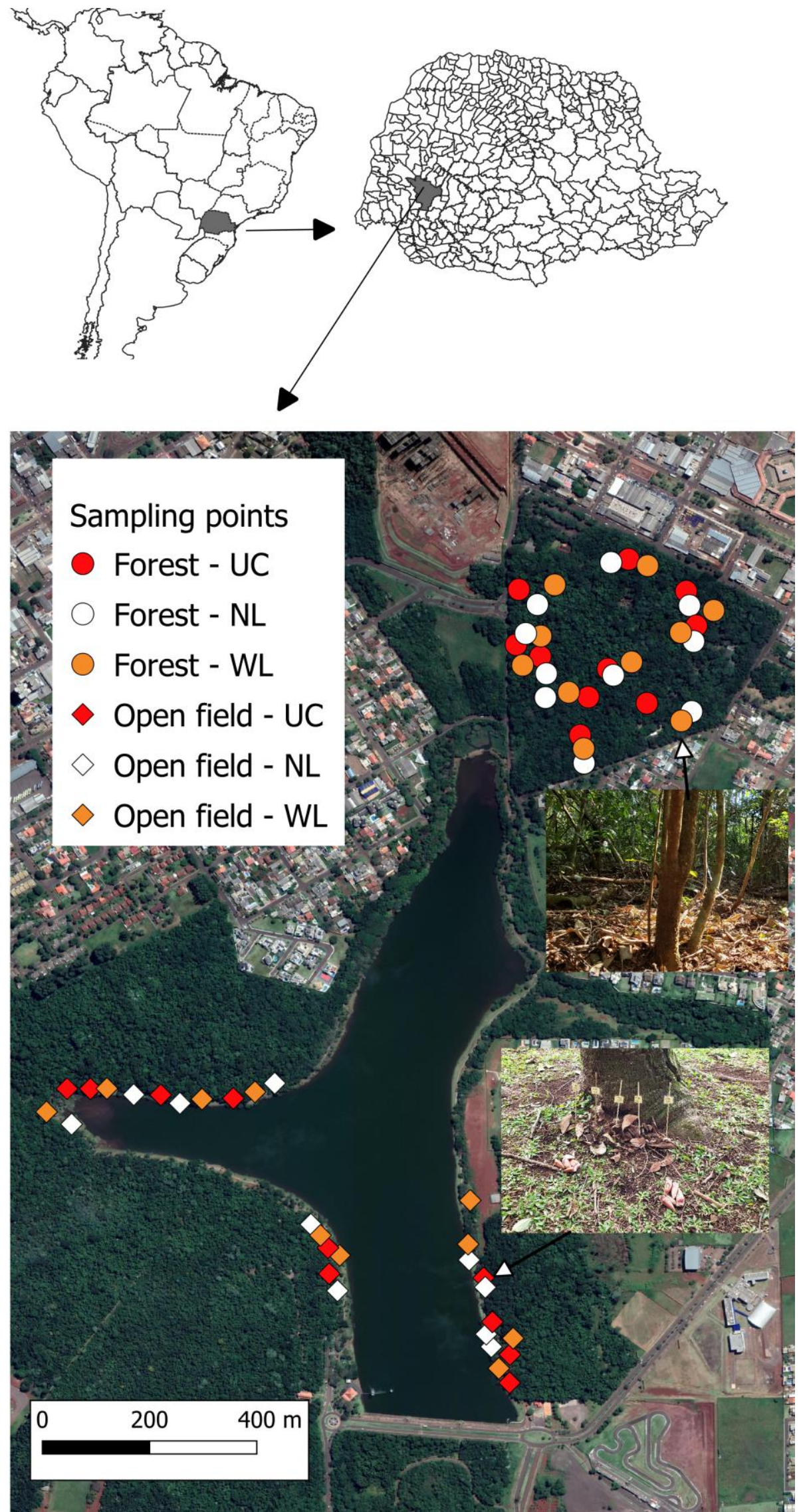

Fig. 1 


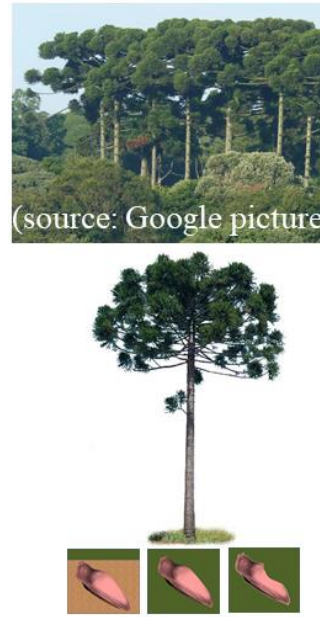

Environment

Legend

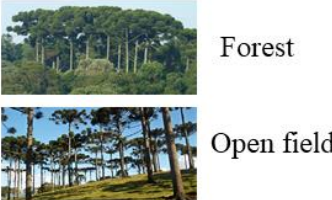

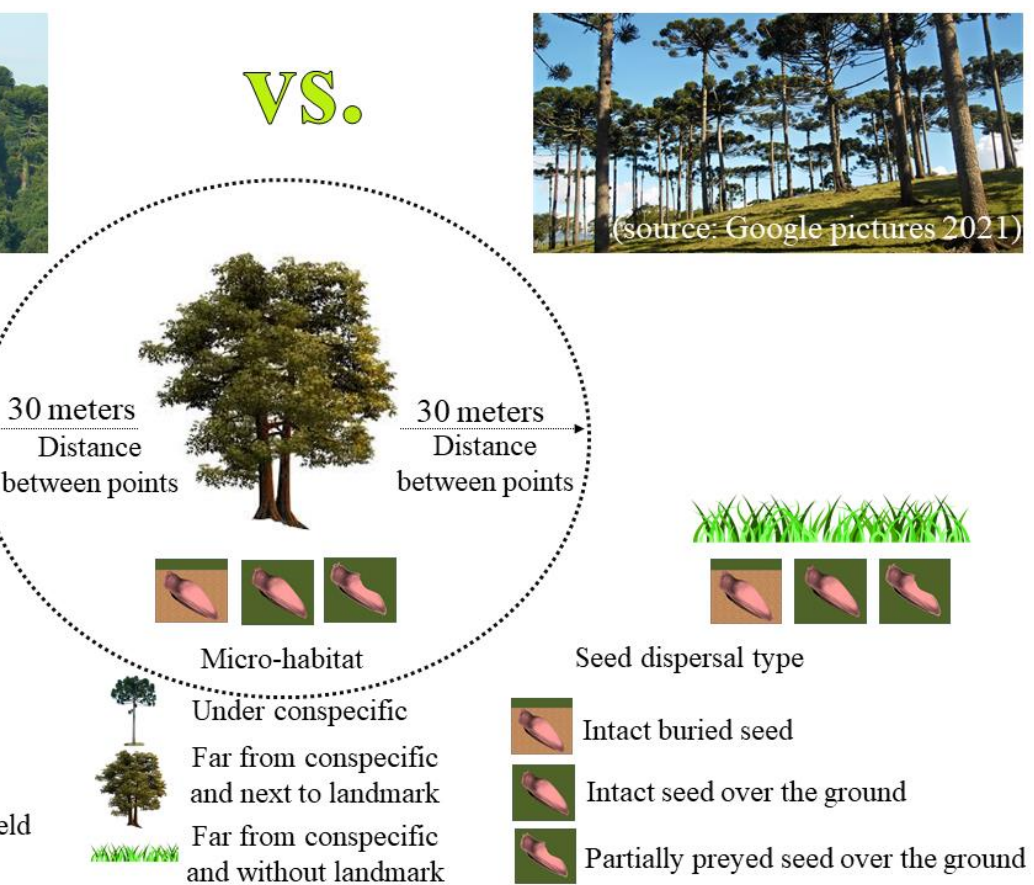

611 Fig. 2

612

613

614

615 

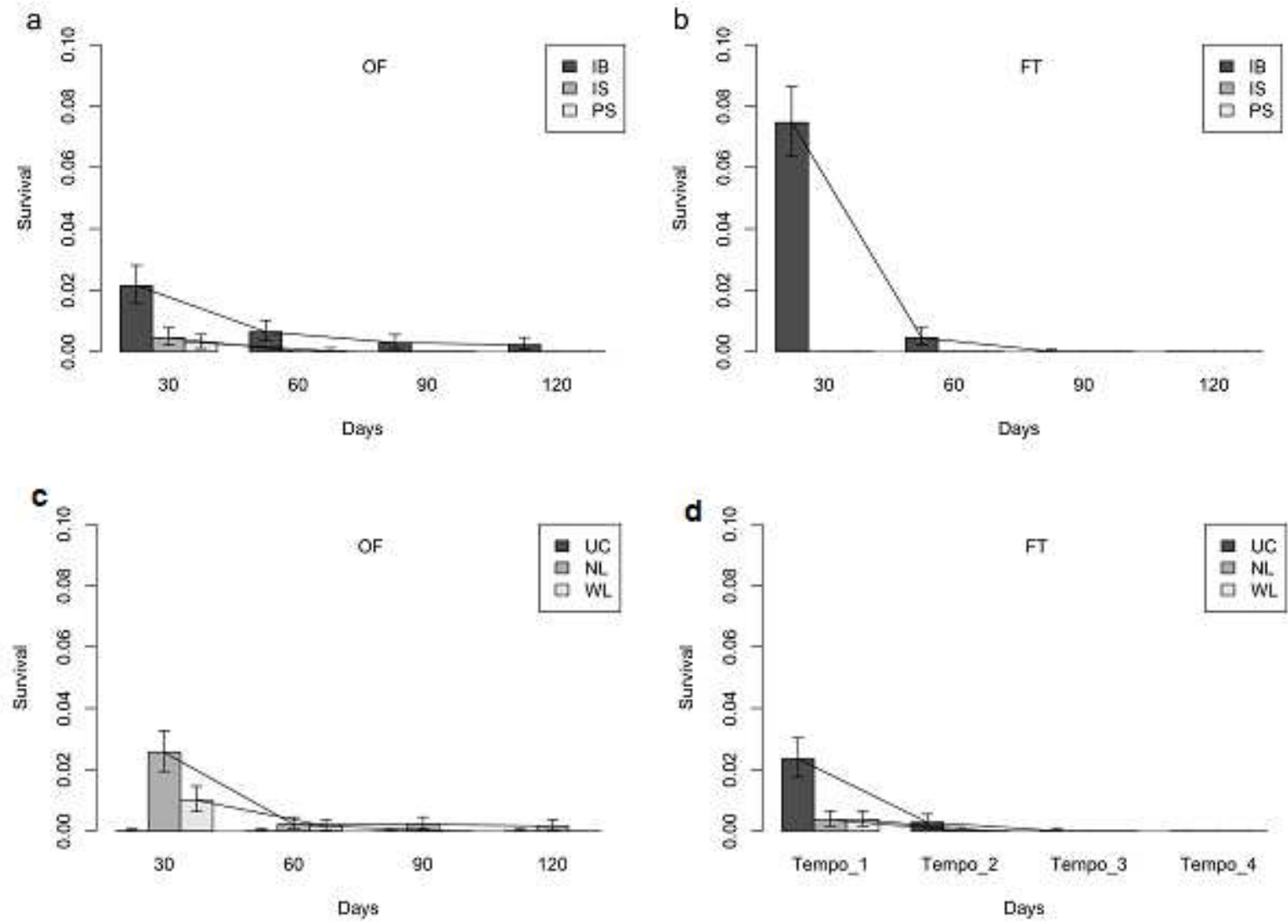

616

617

Fig. 3 

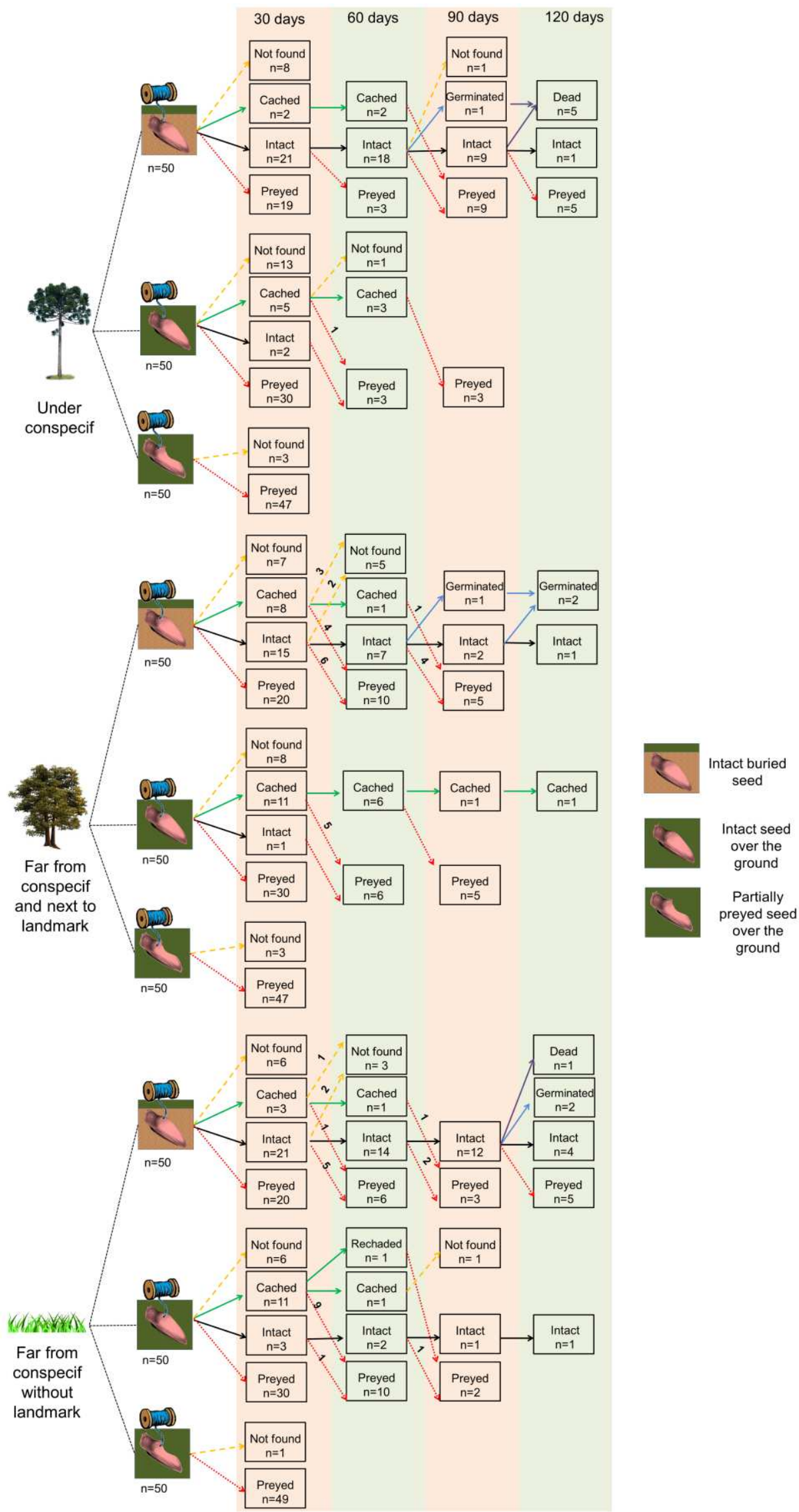

Fig. 4 


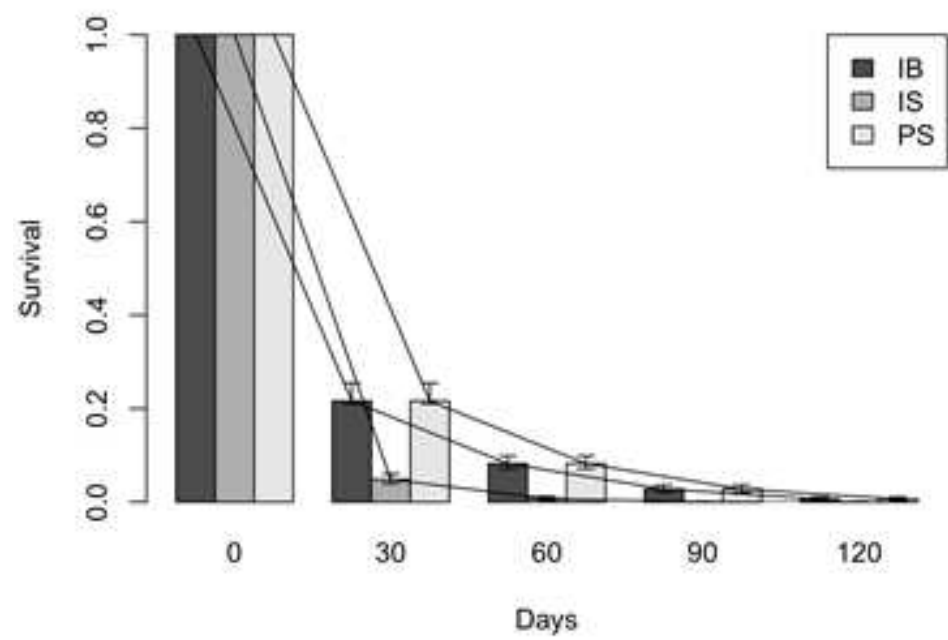

620

$621 \quad$ Fig. 5

622

623

624

625

626

627

628

629

630

631

632 


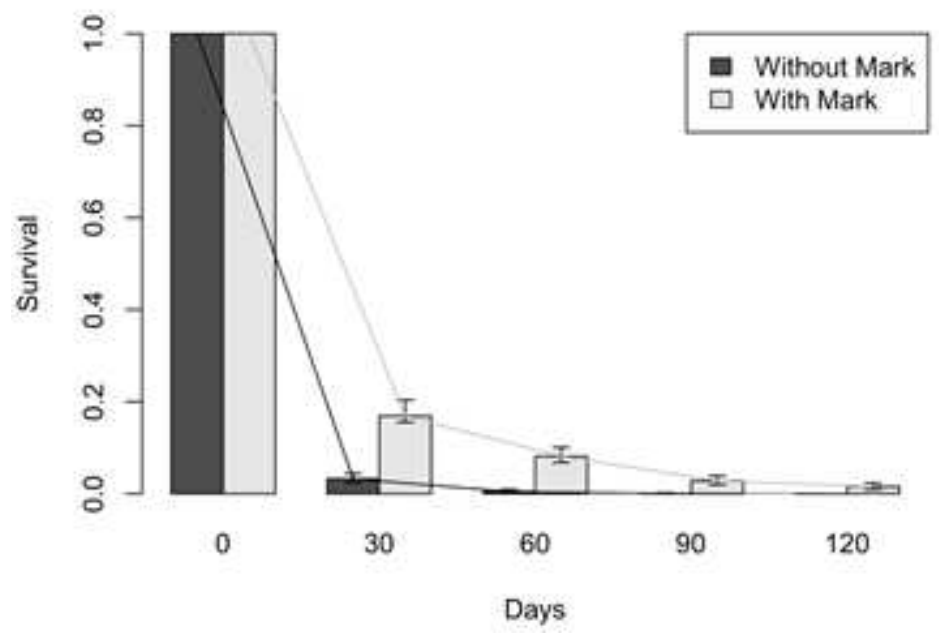

633

634 Fig. 6

635

636

637

638

639

640

641 


\section{Supplementary Files}

This is a list of supplementary files associated with this preprint. Click to download.

- Suplementaryfiles11.pdf 